\title{
Reflections
}

\section{Hand 2061}

\author{
M Felix Freshwater \\ Voluntary Professor of Surgery, University of Miami, School of Medicine, Miami, FL, US
}

Address for correspondence: Prof. M. Felix Freshwater, 9100 S. Dadeland Blvd. Suite 502, Miami FL 33156-7815 US.

Email: mfelix.freshwater@gmail.com

\section{WHY?}

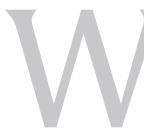

hy have an essay titled 'Hand 2061' in a Hand Surgery issue? Two factors influenced my choice - first, by writing 'Hand' alone I am not limiting myself to surgery; second, the year 2061 is not only 50 years from now, but also is when India will have 1.65 billion people and be the most populous country on earth ${ }^{[1,2]}$.

Last week I was watching Stanley Kubrick's seminal science fiction film 2001 - A Space Odyssey. I still remember its summer of 1968 premiere and, I am reluctant to admit, the many times that I saw the film that summer attempting to decipher its imagery and enjoy its music. Over forty years later, many of the scientific flights of fancy that were supposed to have happened in 2001 still have not come to pass, e.g., colonization of the moon, a giant space station with hotel rooms orbiting the Earth, travel to Jupiter and a sentient supercomputer. Other conceits from the film have become extinct - Pan Am Airways no longer flies planes let alone rockets to the moon. Thus, my 'predictions' for 2061 are tempered by the fact that, with all due respect to Arthur C. Clarke, Kubrick's co-author of 2001, sometimes science fiction outpaces science fact.

\section{HOW?}

How will India provide the highest level of hand care to

\begin{tabular}{|l|l|}
\hline \multicolumn{2}{|c|}{ Access this article online } \\
\hline Quick Response Code: & Website: \\
\hline
\end{tabular}

Indian Journal of Plastic Surgery May-August 2011 Vol 44 Issue 2 its 1.65 billion citizens in 2061? How will patients with hand problems be cared for in 2061? How will we learn about advances in the field in 2061 ?

\section{BACK TO THE FUTURE}

The summer of 1968 was a gap between my graduating from college and enrolling in medical school. I worked as a computer programmer for the now defunct Mergenthaler Linotype Company. Ottmar Mergenthaler, a German immigrant to the US, had invented the Linotype machine in the $19^{\text {th }}$ century. Linotyping remained the dominant system for printing for most of the $20^{\text {th }}$ century. In 1968, the company's two largest customers were the R. H. Donnelley Company that published telephone directories and the US Department of Defense that published parts catalogues. The problem that these customers faced was similar to the problem that the US Census Bureau faced before it adopted Hollerith cards, commonly called punch cards, produced by what would become the International Business Machine Corporation (IBM). Without adopting this 'new' technology, it would have been physically impossible for the Census Bureau to complete its analysis of the 1890 census before $1900^{[3]}$. Similarly, the tasks of updating telephone directories and parts catalogues had become so time consuming that it was becoming physically impossible for these publishers to create current content using Linotype machines. With that in mind, Mergenthaler Linotype embarked on a project to develop software and hardware for an optical recognition system.

In 50 years, India will face a problem similar to that faced by the US Census Bureau in 1890 and the publishers in 1968 , i.e., the population's growth will have outstripped the means by which present day technology is capable of solving its future problems. Currently, the Bill and Melinda 
Gates Foundation is devoting a substantial portion of its resources to "save lives in poor countries ${ }^{[4]}$. It is accomplishing this by initiatives in preventive medicine, family planning, nutrition, maternal neonatal and child health, tobacco control and ways to treat and prevent a host of infectious diseases.

\section{A PATH THROUGH ONE GATES}

One pipe dream is to assume that by 2026 the Gates foundation has achieved all of these noble goals and turned its attention to treat other illnesses and injuries. Imagine that by 2061 , a quarter of a century later, the Gates Foundation's efforts have yielded drugs derived from salamanders' limb regeneration abilities, apply them to humans and have the final product, i.e., a normal limb, available within a brief period of time ${ }^{[5]}$. Then, we who treat hand illnesses and injuries would be relegated to the role of parts replacers similar to the technicians who 'repair' modern day electronics. Perhaps there would be no role for humans and autonomous robots would replace the parts. ${ }^{[6]}$

\section{ANOTHER PATH}

For those of you, who see this dream as too fanciful; let me offer some proposals by which we can improve the care of patients with hand problems. Many of these proposals based upon extant technology merely require organization and adaptation to the hand.

If I arrogantly assume that the current US ratio of hand surgeons to patients is ideal, then for India to reach that ideal ratio by 2061 it would be necessary for India's medical colleges to train nothing but hand specialists. Unless India were to increase the number of its medical colleges and/or the size of their graduating classes substantially, there would be no room to educate any of the other specialties or even primary care physicians. Clearly, this would be both an impractical and untenable public health policy. Hence, we must develop more effective, efficient and practical means to evaluate and treat patients and educate practitioners.

\section{EVALUATE PATIENTS}

Clearly, a solution for evaluating patients more effectively and efficiently must be developed without pouring the most precious resource - manpower, into the breech.
Fortunately, India already has a mechanism in place to accomplish this and already has attained eminence in the field. The solution is call centres. Currently, call centres are limited to inquiries from customers seeking financial information or technical support for electronics and software. However, it is readily feasible for the principles of the call centre to be applied to providing baseline diagnosis and treatment recommendations for common hand problems. I am not recommending that the call centre representatives will tell the patient with a thumb amputation, "Take two aspirins, put the part in the fridge and see a doctor in the morning". Rather, many ills and injuries are diagnosable by telephone today with a relevant history and even more are accurately diagnosable with digital images. If, by 2061, a system were in place that allowed patients or their parents to contact a 'Hand Centre' by Smartphone or webcam, then more patients could be promptly and properly treated with more complex problems escalated to a higher level of expertise, just as is done with current call centres.

\section{ADVANCES IN DIAGNOSIS}

More sophisticated imaging has improved our current abilities to diagnose hand problems. I believe that this will continue to be enhanced with lighter, faster and less expensive equipment so that by 2061 we will have portable, real-time, high resolution Magnetic Resonance Imaging (MRI) scans that will enable us to better understand what injuries our patients have sustained. For example, rather than guessing or relying upon clinical judgment to determine how extensive the zone of injury is for an avulsion, crush or electrical injury, we will have an MRI capable of showing an advanced form of the STIR2 sequences that is a colorized model of extent of the injured tissue that demands debridement.

\section{ADVANCES IN TREATMENT}

Imaging will also enhance our abilities to treat patients. We know all too well that every time we operate on the hand we must strike a balance between exposure and scar production. Imagine imaging that will allow even more minimally invasive procedures - advanced fiberoptics coupled with 3D- real-time MRIs will be able to identify specific structures that require repair. Aided by pattern recognition software, surgeons shall be readily able to distinguish between a median nerve and a palmaris longus tendon while operating without tourniquets.

Indian Journal of Plastic Surgery May-August 2011 Vol 44 Issue 2 
Advances in healing will come from adhesives that can be applied endoscopically and yield superior results in restoring structural integrity while minimizing secondary scar tissue.

\section{TRAINING PRACTITIONERS}

With the growth of digitally organized clinical data, many questions raised through the evidence-based medicine approach will have ready answers. Data from 1.65 billion people will mean that it will no longer take years to gain statistical power for clinical studies and practitioners will be able to learn what diagnostic tests and treatments are most effective by accessing available databases. As they will be able to learn about the current state of the art and science of the hand by access to the Internet, practitioners will have no need to attend scientific meetings except for their social value. Printed textbooks will exist only in rare book libraries and the only time that a printed version of this issue of the Indian Journal of Plastic Surgery will be read is to see how patients and practitioners coped with the primitive methods of the early $21^{\text {st }}$ century compared to the state-of-the-art methods available in 2061.

\section{REFERENCES}

1. Freshwater MF. Are we hand doctors or hand surgeons? J Hand Surg 2011;36:945-6.

2. Available from: http://www.gatesfoundation.org/global-health/ Pages/overview.aspx [Last accessed on 2011 May 06].

3. Available from: http://www.en.wikipedia.org/wiki/Herman_ Hollerith [Last accessed 2011 May 06].

4. Available from: http://www.gatesfoundation.org/global-health/ Pages/overview.aspx [Last accessed on 2011 May 06].

5. Burd DA. Salamanders, lizards and ubiquitous stem cells. J Plast Reconstr Aesthet Surg 2008;61:121-3.

6. Available from: http://www.en.wikipedia.org/wiki/Autonomous_ robot [Last accessed on 2011 May 06].

How to cite this article: Freshwater MF. Hand 2061. Indian J Plast Surg 2011;44:368-70.

Source of Support: Nil, Conflict of Interest: None declared.

\section{Announcement}

David M. Freshwater has prepared a Catalogue raisonné of $D$. Ralph Millard's publications. It has hypertext links to those items indexed in PubMed, and it can be accessed via this link http://calder.med.miami.edu/Ralph_Millard/bibliography.html

Through the kind offices of the Millard family, access to digital copies of D. Ralph Millard's Cleft Craft volumes 1-3 and A Rhinoplasty Tetralogy can be freely obtained via this link http://calder.med.miami.edu/Ralph_Millard/ebooks.html 